\title{
Reliving Island Life: Staging Stories of the Blasket Islands
}

\author{
Daithí Kearney \\ Dundalk Institute of Technology, Ireland
}

Copyright (c) 2017 by Daithí Kearney. This text may be archived and redistributed both in electronic form and in hard copy, provided that the author and journal are properly cited and no fee is charged for access.

\begin{abstract}
The Blasket Islands are located off the south-west coast of Ireland. No longer inhabited, the Great Blasket Island and its distinctive culture have been documented by a variety of writers and are celebrated today in an interpretative centre on the mainland and in performances by Siamsa Tíre, The National Folk Theatre of Ireland. "Siamsa" developed from local initiatives in North Kerry during the early 1960s and is located today in Tralee, Co. Kerry. It aims to present Irish folklore and folk culture through the medium of theatre involving music, song, dance and mime but invariably no dialogue. In this paper, I focus on the production Oiléan, based loosely on the stories of the Blasket Islanders, which was initially devised as part of the fiftieth anniversary commemoration of the departure of the last inhabitants of the islands in 2003.
\end{abstract}

Key Words. Folk Theatre, Siamsa Tíre, Blasket Islands, Irish Traditional Music.

Resumen. Las islas Blasket están situadas frente a la costa suroeste de Irlanda. Aunque ya no están habitadas, a lo largo de la historia distintos escritores han documentado lo más distintivo de la cultura de la isla principal o Great Blasket; asimismo, un centro de interpretación en tierra firme da testimonio de su legado, como igualmente lo hace Siamsa Tíre, el Teatro Popular Nacional de Irlanda. La compañía "Siamsa" se desarrolló a partir de iniciativas locales en la zona del norte de Kerry a principios de los años 60 del siglo XX y hoy tiene su sede en Tralee, en el condado de Kerry. Su objetivo es el de presentar el folklore irlandés y la cultura popular a través de un tipo de teatro que contiene música, canciones, baile y mimo, pero con ausencia de diálogos. Este ensayo se centra en la producción Oiléan, basada a grandes rasgos en las propias historias de los isleños. Este espectáculo se concibió para conmemorar en 2003 el quincuagésimo aniversario de la partida de los últimos habitantes de las islas.

Palabras clave. Teatro popular, Siamsa Tíre, islas Blasket, música tradicional irlandesa. 


\section{Introduction}

Siamsa Tíre, The National Folk Theatre of Ireland, has developed a form of folk theatre that aims to present on-stage material that draws from Irish folklore and traditions, not only in a creative and aesthetically pleasing manner but also in a way that presents opportunities for audiences to engage with folklore and stories of the past. In Oileán, a folk theatre production interpreted as "island", the company draws upon the traditions, customs, narratives, tunes and sayings of the Blasket Islands and, in particular, the Great Blasket Island, as documented in the works of many authors who visited or lived on the islands in the first half of the twentieth century. Although the Great Blasket Island is no longer inhabited, the production Oileán provides an opportunity for a second life to the folklore and customs of the island and presents it for an audience that is often comprised of tourists from many different parts of the world. The folk customs of the now uninhabited islands are transformed by theatrical mediation and represented in a manner that celebrates what is gone and creates something new for a theatre-going audience in the nearby space of the Siamsa Tíre Theatre and Arts Centre in the town of Tralee, Co. Kerry, approximately $75 \mathrm{~km}$ from the island.

The motivation for the production Oileán came in part from plans to commemorate the departure of the final residents from the Great Blasket Island on 17 November 1953, an episode that is represented in the production. The sense of loss and passing is expressed in the phrase "Ní bheidh a leithéid arís ann", translated as "there shall not be their like again", taken from Tomás Ó Criomhthain's Irish-language autobiographical novel An tOileánach (The Islandman) (1929). Ó Criomhthain (1856-1937) chronicled a way of life for the people of his community on the Great Blasket Island that gradually declined until it was finally evacuated in 1953. Ó Criomhthain's books, along with those of Peig Sayers (1873-1958), Muiris Ó Suilleabháin (1904-1950) and others, may be termed the Blasket library and are hugely significant not only for scholars of linguistics but as a window into Irish folk culture and folk life. As well as providing a description of a way of life, the books provide an insight into meon na ndaoine or mindset and way of thinking of the people, which Siamsa Tíre founder Pat Ahern believes essential to understanding "folk". As Foley (Step Dancing 215) notes, a sense of community is both a recurring theme in the productions of the company and a characteristic of those involved.

Oileán was first produced as part of the fifty-year commemoration of the Blasket Islands evacuation, which was prompted by official government policy. Echoing some of the complexity of commemorating the 1916 Rising, there is an attempt to balance the celebration of the islands' culture with the loss and emigration entailed by the evacuation. Living through the government-appointed Decade of Centenaries, it is worth reflecting on Fintan O'Toole's remarks:

The idea of an island had a special importance for the independent Irish state that was established in 1922. For the young country, the Blasket and Aran islands had, as well as their echoes of Greek myth, a more specific aura of pre-history. They were part of the creation myth of the Irish state in which, as John Wilson had put it 'the western island came to represent Ireland's mythic unity before the chaos of conquest ... at once the vestige and the symbolic entirety of an undivided nation.' They were a past that would also be a future. Their supposed isolation had preserved them from corruption, kept their aboriginal Irishness intact through the long centuries of foreign rule. (The Ex-Isle 112)

Alongside commemorations of the 1916 Rising and other events, it is imperative that the importance of commemorating what it was that people were fighting for is remembered. That includes the survival of Irish culture as exemplified in a regional form by the writers of the 
Blasket Islands and presented today by Siamsa Tíre. On their website and promotional material for Oileán, Siamsa Tíre state:

This production celebrates life on the Blasket Islands in times past, exploring the way of life of the islanders and their spirit of survival. Oileán captures the essence of this island community, their traditions and customs, their wealth of song and story, their love of life and their strong kinship with one another. (Siamsa Tíre)

This description mirrors the earlier productions of Ahern's, notably Fadó Fadó, in which the customs and ways of life in a North Kerry farming community are brought to life on stage with scenes representing thatching, milking cows and making butter with accompanying Irishlanguage song.

Siamsa Tíre has developed its artistic craft along similar patterns and paths to those employed by other international folk dance companies of the latter half of the twentieth century, presenting on-stage dramatized folk culture using traditional music, song and dance but, as Foley asserts, developing as a folk theatre rather than a folk dance company (Step Dancing 147). In many instances, they move beyond the folk dance remit of numerous other European folk dance groups to develop a form of staged "folk theatre" that embraces the potential of theatre and the development of narrative (see Shay). The Irish language is central to the philosophical roots of Siamsa Tíre, which retains a training centre at Carraig in the West Kerry Gaeltacht, although many of its members are not fluent in the language. While the majority of the song repertoire used by Siamsa Tíre is in the Irish language, the majority of productions do not employ spoken dialogue, instead presenting narrative through dance, mime and gesture.

In this paper I briefly consider the development of Siamsa Tíre and the form of folk theatre that it presents, acknowledging the position of Oileán within the wider repertoire of the company. Throughout the paper I consider the potential use of music, song and dance in commemorative theatrical productions, primarily from the perspective of an ethnomusicologist informed by ethnographic research that includes reflecting on participant observation "at home" with a community that I was a member of, prior to engaging in

fieldwork (see Titon). At the beginning of a number of sections, I provide some short ethnographies of performance drawn from my experiences of the production. The process of devising folk theatre productions is itself a learning experience through which cast members rediscover meanings or translate old customs and stories for a contemporary audience. In turn, the audience interpret the experience from their perspectives, hopefully enjoying the inclusion of music, song and dance as part of an aesthetic experience. While Runia suggests that the often positivist approach to commemoration has deterred historians from engaging in thorough studies of commemoration, through a critical evaluation of the creative and devising process, as well as performances of the production, I will examine how the company have removed the focus from the departure from the Great Blasket Island in 1953 to a celebration of the unique culture and creativity of the people who lived there. Oileán provides a frame through which the stories of the Blasket Islanders may be re-read and experienced afresh. There is a sense of a timeless world lost in time brought to life by the characters that inhabit this dimension and are present in front of an audience. The islands, now abandoned, live on in a stylised and theatrical manner in the performances of Siamsa Tíre.

\section{Siamsa Tíre}

Siamsa Tíre, the National Folk Theatre of Ireland, developed from community-based activity in North Kerry in the early 1960s under the direction of a local curate, Pat Ahern (Foley, Step 
Dancing; Kearney, "The Evolution", "Siamsa Tíre", "Pioneer"; Phelan). Ahern's initial appointment to St John's parish in the town of Tralee in 1959 required him to establish a choir and, over the following decades, he would conduct this choir and develop a number of pageants on religious themes. A television series, Aililiú, a type of variety show based on traditional themes and first broadcast in 1965, marks the establishment of a folk theatre company, Siamsóirí na Ríochta, which went on to present on stage a musical culture and way of life lived by people in Kerry in the early twentieth century. They began performing fulllength stage productions during the summer of 1968 and the "summer season" performances have continued into the present (see also Motherway; Foley, Step Dancing; Phelan). The company has developed and expanded over the past six decades but remains located in Kerry, largely comprised of a community (non-professional) cast. Renamed and reconstituted as Siamsa Tíre and acquiring the title of the National Folk Theatre in the 1970s, the company has a purpose-built theatre in Tralee, two training centres and an ever-increasing repertoire. The theatre is an important element of local tourism and audiences during the summer months are comprised largely of tourists, requiring consideration of the impact of tourism on local culture. $^{2}$

The early productions of the group that became Siamsa Tíre were inspired by the lives of the people involved, in particular Pat Ahern. A fiddle player himself with a strong interest in the Irish song tradition, Ahern combined music, song and dance with theatricalised representations of Irish rural life, which included various tasks and social aspects common in rural north Kerry in the early twentieth century. Amongst the productions are Fadó Fadó (1968) and Ding Dong Dederó (1991) which focus on the experience of life in North Kerry; the latter representing the life and legacy of the North Kerry dancing master Jeremiah Molyneaux (from whom Ahern himself had learned). Particular influences that become identifiers of Siamsa Tíre's performance practice are the use of the choral arrangement of traditional songs in the Irish language (often arranged by Ahern), the Munnix style of dance and the development of contemporary choreography incorporating Irish traditional step dance. Oileán too draws on the lives and memories of real people, representing their stories and culture on stage.

Described as "[t]he most traditional and, at the same time, original Irish theatre performance of which music and dance are an integral part" (Swift and Morash 482), there is an inherent conflict between the old and new in the work of Siamsa Tíre. In the context of developments in dance in Ireland, long-time dance critic Diane Theodores ("Report") indicated a desire for an Irish theatre dance style that she believed could emerge from the work of Siamsa Tíre which was merging the traditions from the archives with new and external ideas. In all outputs by Siamsa Tíre, including Oileán, there is a balance between innovation and tradition, constantly drawing on the past for inspiration while simultaneously drawing on external artistic influences. ${ }^{3}$ Jonathon Kelliher, the original lead dancer in Oileán who succeeded Oliver Hurley as Artistic Director of the Company has stated:

As the National Folk Theatre of Ireland our remit is to portray our traditions. We are trying to keep our traditions, but still move them forward into the twenty-first century - without stagnating. We don't want to be like most folk groups in other European countries. We keep our traditional dance as it is. We haven't strayed and gone with the modernization of the Irish dance. We've kept it, and developed it in its own way. Being the National Folk Theatre - folk being the people - we try to tell the stories of the people. (qtd. in Mulrooney 53)

If Oileán is interpreted as a commemorative practice, it is also reflective of contemporary cultural practice in Kerry. As Guy Beiner notes, "Commemorative practices can be integrated 
into everyday life and can take place in different spheres of social interaction. Although it may be easier to conduct historical investigations of well-documented, large-scale major public commemoration celebrations, the study of commemoration should be sensitive to different levels and theatres where the past is re-enacted through ritual" (62). While the productions of Siamsa Tíre may be modelled on older folk traditions and cultural expressions, the performances are essentially exhibits of those who make them (Kirshenblatt-Gimblett 2). Chief amongst the consumers are tourists and Foley notes the efforts the company engages in to attract groups of tourists and highlight their international appeal. Foley also acknowledges the influence of cultural tourism and the potential for regional economic development through the commercialisation of a "folk theatrical re-presentation of cultural heritage" ("Cultural Tourism" 143). While Ahern acknowledges potential for tourism in the 1972 plan that led to the development of the theatre in Tralee, there is a desire to capture the essence of Irish life. In this document, Ahern places special emphasis on the language, which reinforces the potential for Oileán to embody and realise the underpinning aims and philosophies on which the company was founded.

While Ahern was the Artistic Director and dominant voice from the 1970s to the 1990s, the establishment of a professional company in 1985 created new potential for artistic development and this group looked out beyond local traditions to incorporate new influences. Composers including Mícheál Ó Suilleabháin, choreographers such as Mary Nunan, and directors, including Michael Scott, contributed their creativity to the development of the company. It was a member of the original "Core Company" that developed and directed the production Oileán. Oliver Hurley joined Siamsa Tíre as a child, auditioned and put through rehearsals by Ahern himself (Hurley, Interview). His early involvement included a part in the company's Broadway cast for Siamsa in 1976 and he went on to become part of the first core company in 1985 before being appointed Assistant Artistic Director in 1988. Later, he directed the 1993 production Samhain while Ahern was still Artistic Director, before becoming Artistic Director himself in 2001 following the departure of then Artistic Director John Sheehan (Kearney, "Shamhain"). Hurley stood down from this post in 2007 having expanded the company's repertoire and overseen a number of touring productions in Ireland.

\section{To the Islands}

Following an overture performed live by a small ensemble usually consisting of tin whistle, flute, fiddle, button accordion and piano, the soundscape becomes mechanical, created by percussion and various metal objects. The auditorium lights dim and the audience view a black, bare stage. Dancers emerge on stage dressed all in black, walking in rigid straight lines, turning always at right angles, narrowly missing each other as they focus only on their own path, pausing occasionally to dance a rhythmic motif. Coming together as if on a bus or a train, the group quickly disperses again, eventually leaving the stage apart from one individual who remains as the mechanical soundscape is replaced by a melodic motif, introduced first, in short phrases, on the piano, before developing into a gentle arrangement with harmonic colour. The dancers' movements are fluid and light in contrast with the straight lines of the preceding section. A gauze is backlit to reveal the island. Gradually characters emerge, calling place names from the island in the Irish language. ${ }^{4}$ Soon the scene is complete and the characters go about their tasks - mending nets, gathering seaweed, preparing lobster pots, and gossiping. ${ }^{5}$

Oileán (2003) presents a series of short scenes that attempt to encapsulate life on the Blasket Islands, borrowing from the work of a number of writers who lived on or visited the Great Blasket Island before the final inhabitants left in $1953 .{ }^{6}$ The Blasket Islands are located near 
the Dingle peninsula off the south-west coast of Ireland. Uninhabited today, its fame owes much to the literature in the Irish language produced by a number of the island's inhabitants in the 1920s and 1930s describing their unique way of life in a remote place. Recognising the role of the Irish Folklore Commission in the dissemination of knowledge, Bo Almqvist also argues that "there are all over Europe thousands and thousands of people who know more about the Blasket Islands than about Tralee or Galway and more about Tory Island than about Letterkenny" (18). There have been repeated calls for the islands to be designated a UNESCO World Heritage site in order to protect the unique cultural and natural heritage (Lucey; Hickey).

Mirroring the politics of time and modernity that has placed the future of the Blasket Islands at the centre of debates on planning for development and tourism, one aspect of the Oiléan production is the contrasting of life in the past and present, echoing Ó Giolláin's consideration of "the end of tradition" $(17 ; 173)$. The way of life on the Great Blasket Island has been extinguished but the tradition is carried on, preserved in part through the literature of the island writers, folk memory and, since 2003, in the theatrical presentation devised by Siamsa Tíre. The challenge is to understand the work of Siamsa Tíre as something new, drawing on an understanding of "heritage" as something that is new. Barbara KirshenblattGimblett defines heritage as "a mode of cultural production in the present that has recourse to the past", arguing that heritage "depends on display to give dying economies and dead sites a second life as exhibitions of themselves" (7). Siamsa Tíre have created heritage from the cultural legacy of the island people and given it a second life on the theatre stage. ${ }^{7}$ Other forms of display include a museum, visitor and interpretive centre Ionad an Bhlascaoid Mhóir (The Blasket Centre) at Dunquin on the Dingle Peninsula and the remains of buildings on the Great Blasket Island where a number of writers' homes have been painted white and are, thus, visible from the mainland.

By drawing on local traditions through engagement with various forms of documentation and sources and performing them on the stage, Siamsa Tíre are enacting in one way Lauri Honko's concept of a "second life of folklore" (Honko). The challenge in the context of the Great Blasket Island and the related traditions and folklore is that there no longer exists a local community on the island. Instead, the island's culture has become imagined as part of a broader national culture, imbued with significance through the romanticisation of island life and lore, and presented on a theatre stage by professional performers for a paying audience. Nevertheless, a local identity remains important for people living on the mainland for whom the islands remain a visible reminder of the culture that existed there and there is a sense of pride amongst the performers of the culture of their place. Siamsa Tíre has developed a "second life" for this folklore, albeit in a recycled form and removed from its original social contexts. In this "second life" it becomes accessible to a wider audience and becomes a pathway for further engagement with the folklore and traditions of the Great Blasket Island.

The human fascination with islands has existed since antiquity (Lowenthall) and islands are a recurring device in Irish theatre. From Synge's The Aran Islands (1907) to Barry's Prayers of Sherkin (1990), as in the writings of the Blasket Islanders, the island embodies a fixed, pure, unified entity that is a microcosm of the nation (O'Toole, "Irish Theatre" 50; 55). Islands recur in Irish theatre, not just as a physical place but a metaphor for remoteness, both in space and time, and as a counterpoint to modernity (Morash and Richards). Focusing on islands, John Gillis notes that remoteness can imply physical distance but also "travel through time" (40). Oileán attempts to bring the audience back in time, a common feature of tourist sites or attractions (Gibson and Connell 17). Oileán, like many of the productions by Siamsa Tíre, is at once both a theatrical experience and a tourist attraction; 
both traditional and contemporary, linking the remote rural and immediate urban spaces that the audiences may encounter in Ireland, even as part of a brief holiday experience.

Oileán was devised by a creative team inspired by stories from the Blasket writers including Peig Sayers and Tomás Ó Criomhthain, whose books are celebrated for their depiction of Irish life at the most westerly point in Europe. The significance of this source material is outlined by scholars such as Eamon Maher who stresses the importance of the Blasket autobiographies and the place of the Blasket Islands themselves in the imagination of Irishness which is traditionally linked to the west of Ireland (Maher). ${ }^{8}$ The importance of these stories was reinforced by the fact that, for a generation of school children in Ireland, Peig (1936) was a core curriculum text. Like these books, the production represented a return to attempts at capturing a particular milieu, a "romantic and idealised notion of island culture that often occluded the harsh reality of those trying to eke out an existence on these outposts from the limited resources at their disposal and in the absence of an efficient means of communicating with the mainland" (Maher 264). Describing An tOileánach as one of the more important documents of Gaelic culture from the early twentieth century, O'Toole notes:

what is striking is the way in which every action, every word, every person, has meaning only in relation to a whole, a whole that is defined by the timeless truths of custom. The view of reality that we get is never a personal view. At no time is it at variance with the values of the society as a whole. ("Irish Theatre" 50)

Thus, the book resonates with the central goal of Siamsa Tíre, to present and represent a folk culture that is reflective of a community and which has shared universal elements that can be identified across all human cultures.

There are a number of unnamed characters in Oileán who serve dramatic purpose and who may be viewed in the context of other characterisations in Irish theatre. For example, O'Toole outlines a sense of doubleness that emerges in Irish theatre, sometimes represented by the character of the outsider ("Irish Theatre" 48; 53). In Oileán this happens twice. First, the visitor from another time (the present), representing the audience, allows the modern world to be seen to contrast greatly with that of the islands. Secondly, a character from another place, representing the character of Robin Flower but generalised as "the stranger", is like a tourist, viewing and documenting the islands' culture. ${ }^{9}$ Both characters are encountering an idealised world that is different and remote from their own, but one of the messages of the production would suggest that it is also a part of and within reach of their own world.

\section{Creating the Performance}

A simple work song is performed in four-part harmony, giving way to energetic dancing and wild screams. Characters emerge and return from the crowd. The schoolteacher struggles to gain control over the unruly schoolchildren who beat their feet in unified rhythm. Two boys go hunting rabbits on the cliffs from where they see a shipwreck being washed ashore. The islanders dance to celebrate their treasure. A young man and woman play the game of love that eventually leads to marriage. The young couple lead their neighbours in a dance. A young girl gets a letter from America with money for passage. The community dance at her American wake. Women sing a religious song on the headland in lieu of mass before the returning men engage in a danced game of hurling ${ }^{10}$ on the beach. Singers and dancers demonstrate their talents to visitors who are curious about the strange ways of the islanders. With each passing scene, the narrative is carried by music, song and dance. 
Even though music, song and dance played a dynamic role in the lives of the island community, ${ }^{11}$ Oileán draws its inspiration primarily from living sources for music, song and dance. Many of the songs were sourced from West Kerry singer Máire Ní Bheaglaíoch (Maura Begley) but to this tradition was added a number of traditional tunes and new compositions by musical director Tom Hanafin, lyricist Muiris Ó Laoire and choral arrangements by Colm O'Brien. In Mulrooney's study of dance in Ireland, Kelliher states: "We did a huge amount of research for Oileán as well - reading all the Blasket books like An t-Oileánach and Fiche Blian ag Fás. For Oileán the musical director got specific songs from the Blasket Island and from West Kerry. We felt that if we were trying to tell the spirit of the island, we should use what they used" (Irish Moves 253). A notable inclusion is the character of a fiddle player who, in early productions, enacted the legend of "Port na bPúcai', an air sourced to islander Seán Cheaist Ó Catháin (d. 1972) but popularised by Seán Ó Riada and subsequent musicians. Like Ó Riada, the fiddle player in the original production, Noel McAulliffe, adapts and shapes the melody having listened to various sources. A recording of McAulliffe is used in some performances of the production. Another notable inclusion is "Caisleán Uí Néill”, a song reputedly sung by Tomás Ó Criomthain. ${ }^{12}$

Much of the music on the island was played for dancing and the instruments used included fiddles, which the islanders sometimes made themselves, and accordions, which remain prominent in the soundscape of west Kerry today. Dancing on the islands included set dancing, which developed in Ireland from the model of the quadrille through the nineteenth century (Brennan 23-27). The islanders themselves were noted for their wildness and there is an attempt in Oileán to capture some of this character in the choreography. The dancing involves full body movements using choreography by Cindy Cummings that fused the Munnix tradition with contemporary dance, borrowing motifs from set dancing patterns but including lifts, jumps and complex foot movements from beyond the local tradition. Placing the choreography in Oileán in the wider context of changing styles of Irish dance and the blending of traditional dance with contemporary movement, theatre critic, Michael Seavor comments:

In Oileán (Island), American choreographer Cindy Cummings deconstructs the traditional vocabulary by underpinning and driving the action with the pulse of heel taps, whether by stationary standing figures or by school-children seated at their desks. This one ingredient of Irish dancing technique becomes a thread through Oileán that is both visual and rhythmic. (12)

The use of this choreography is representative of but not an imitation of the dances of the Blasket Islands. Within the performance, the use of particular step dance motifs from the Munnix dance tradition act as kinaesthetic identity marker for Siamsa Tíre (Foley, Step Dancing 218). Despite the explicit reference to inspiration from the folk, it should not be assumed that tradition is revived by the modern nor that the contemporary must be fed by the folk but rather that there is a symbiotic relationship that exists in the theatre as a space for mediation and creativity.

The three choreographic concepts employed by Egyptian choreographer Mahmoud Reda with the Reda Troupe are evident in Oileán: namely dramatization, imagery and folklore. Dramatization refers to sketches or tableaux, short stories that contain elements of mime, gesture and narrative. The scene in which school children tap out lessons percussively with stone on slate while simultaneously beating time with their feet exemplifies this simple dramatization. According to Reda, "[t]he story music be simple, and its meanings clear, so that it is possible to be depicted through movement" (qtd. in Shay 150). This echoes the opinions of Ahern and of long-time member Jimmy MacDonnell who emphasised the 
development of many of the company's shows from short scenes (MacDonnell, Interview). Many of the scenes in Oileán may be directly or indirectly read in the books of the Blasket Island writers. Imagery is employed through the use of bodies to create a sense of the stormy sea and other aspects of nature or the unseen. The process of devising theatrical performances highlights different ways in which the theatre can interact with folklore and how, by drawing on themes from the Blasket Island writers, different aspects of folklore can be included or excluded to develop both a structured narrative and something to which an audience can relate. An example of folklore in Oileán is the incorporation of the story related to the air "Port na bPúcaí".

Describing the creative and devising process, director Oliver Hurley notes the involvement of west Kerry singer and musician Máire Ní Bheaglaíoch as an important resource for musical heritage and ideas. Initially the creative team undertook workshops in sean nós singing with Begley and found that this influenced the creative process. Despite this desire to engage with the tradition and incorporate music and song from both living and archival sources that could be connected with the islands, Hurley also notes that they did not feel restricted to only using traditional material and musical director Tom Hanafin also composed new music. Hurley notes:

It's important that both could work together. I don't think there is any point in saying 'ok this is a new show and lets just create all new music'. I always felt it worked to come from traditional music. My example is the beauty of the work in Oileán when you had the mass song, obviously 'Port na bPúcaí' and two other songs which she actually told us were sung on the island. You know if we haven't them, we would have lost an awful lot of soul. (Interview)

The inclusion of cultural mentifacts such as songs and airs from the repertoire of the islanders provides a significant if intangible link to the actuality of the islands. The inclusion of "Port na bPúcaî" marks a very direct reference to the musical life and lore of the Blasket Islands. Ríonach Uí Ógaín notes that "This tune is associated with Corca Dhuibhne and especially with Inis Mhic Aoibhleáin in west Kerry. It is also called 'Caoineadh na BhFairies' or 'Caoineadh na Sióg' (The Fairies Lament). Oral tradition says it is magical or fairy music" (72). The story of receiving the tune is included by Robin Flower in The Western Island (Flower 116), highlighting the importance of music in the intersection of the fairy world with the mortal world (Uí Ógáin). In later productions, a decision was made to use a recording of "Port na bPúcaí" without an enactment and removing the narrative of the legend. Commenting on the importance of this piece of music, drawn directly from the island experience, Hurley bemoans:

It still kills me that 'Port na bPúcaí' is not played in that show you know because there's a sense that it is right for it. You know you couldn't compose it. Or you could compose something but consider what you would have lost by not using [Port na bPúcaí]. That, I think, is important. (Interview)

The desire to create direct connections to the islanders and island culture is particularly important in instances where those creating the commemoration have little direct experience of the culture. While the majority of the creative team were not born when the Blasket Islands were abandoned, a number of the cast came from west Kerry, had a knowledge of the Irish language and were already immersed in the presentation of folk culture through the work of Siamsa Tíre. There is a need for the creative team to engage with the fundamental concept of 
folk culture and the living remnants of the culture of the Blasket Islands in order to create and present an informed representation that commemorates the lives and culture of the islanders.

\section{Engaging the audience}

A boy stops at play and a girl, perhaps his older sister, brings him home to his mother. Anxious, she asks his father to get help from the doctor on the mainland. Able to read the skies, the men are aware of impending storms. Nevertheless the father sets out in his small (imagined) currach to reach the mainland. The sea, a group of dancers, move and rise wildly to the music of a fast-paced reel; the sound augmented by rough harmonies and use of percussion. The intensity of sound and dance is brought to a sudden stop by a woman's wail, signalling the death of her young son. The father carries the boy's dead body to be laid out on a stool surrounded by his community. To the sounds of the women keening, ${ }^{13}$ the body is carried to the edge of the stage and then, after a pause, away in silence. The community gather their belongings and gradually ebb away, the final inhabitants singing their boat song as they slowly process up through the auditorium, the soundscape augmented by sobs from the audience. For some in the audience, this represents the leaving of Ireland undertaken by their ancestors. As the sounds of the traditional song fade away, the stage, once again bare and black, is populated with busy people walking in straight lines to the sound of industry.

An important aspect of presenting commemorations through theatrical performances is the potential to create a connection between audiences and the historical events or worlds that are being represented. Examining collective memory, Barry Schwartz states: "Recollection of the past is an active, constructive process, not a simple matter of retrieving information. To remember is to place a part of the past in the service of conceptions and needs of the present" (374). Giving consideration to how a production inspired by history or folklore can be made relevant to an audience, director of Oileán, Oliver Hurley, describes one aspect of the approach to developing a Siamsa Tíre production:

I believe now, having tried it several ways, that you must have emotional connection with the audience. A group like Siamsa Tíre could be seen as a museum piece but it has to be more than that. It can draw you in emotionally. You as a person must connect with what you are seeing. Making that connection is what is important... The idea in Oileán was a very simple. We were going through the whole process of the Celtic Tiger, busy busy, and that was really informed by Máire Begley saying one day she went out to the Blasket Islands ... In one of our sessions she said 'I set out to the island to get away from the humdrum of everyday life' and I said sitting there 'that's the show'. When you go out there you are just removed from the everyday troubles and woes. It's a different feeling out there so that kind of informed the idea of how one could get into bringing the Blaskets back to life. (Interview)

The resultant opening and closing scenes of Oileán feature the cast dressed in contemporary black costume and moving in straight lines to mechanical sounds (see also Foley, Step Dancing). In the opening scene, the discomfort of the modern world, evoked through mechanical sounds, dischords and robotic movement, is interrupted by the chant-like voices of the cast who vocalise placenames on the island, gradually emerging into a performance of everyday tasks including gathering seaweed, mending nets and lobster pots and peeling potatoes. Theirs is a world of colour and communication in contrast with the uncaring dark world from which the audience has travelled. In a subtle nod to the past, original black 
costumes had zips that could be undone to reveal the little bit of colour that represented the island heritage of contemporary society.

In the folk theatre productions of Siamsa Tíre, music, song and dances become devices with which to engage an audience in the commemoration of island life. The variety of songs performed in the production reflects the tradition and include work songs such as "Bád Beag" and love songs such as "An Bínsín Luachra". The development of group dances, similar in style to many international folk dance productions of the latter half of the twentieth century, draws the audience into a "fun in the village" scenario (Shay 57). As Martin Banham notes, "[a]t any point in this continuum the dramatic action may be interrupted by or culminate in music and dance" (379). There is an educational value for those not familiar with Irish life and the folkways and customs of a community that only exists in literature. Anthony Shay notes the use of a popular event such as a wedding as a popular and effective format for the presentation of traditional dance stating: "In this way the choreographer can weave into his or her work customs, special songs, and a wider variety of festive clothing ... The use of context tends to give the work greater verisimilitude. Other effective devices centre around contexts such as work scenes, harvest festivals, rituals, holidays, and other daily activities" (45). These devices are used in abundance in Oileán. Furthermore, the centrality of migration to the story of the islands (Royle 27-54) resonates with many who become part of the audience.

\section{Translating to Create Heritage}

Before the show, the audience arrives in groups, many of them stepping off of tour bus and following a guide into the lobby. On the counter are leaflets in several languages describing some of the content of the production. To one side is a merchandise stand. The building itself is unusual to many who enter, modelled on the remains of a ringfort at Staigue in South Kerry so that the exterior façade could reflect in some way the culture of the stage. Some of the artworks on the wall represent myths, legends and customs from Irish history. As the audience leave, they reflect on their experience in their own languages, clarifying aspects of the narrative to each other. Some purchase souvenirs to take home including programmes and recordings of the music.

Oileán is a translation of the island writings and culture into a theatrical performance. As part of the heritage industry, Siamsa Tíre has created something new. As highlighted by Kirshenblatt-Gimblett in the context of museums: "Much is made of the traditions themselves, as if the instruments for presenting them were invisible or inconsequential" (156). The theatre is an instrument through which the culture is reshaped and presented anew. The productions maintain sounds of the Irish language primarily through use of song and visually portray aspects of life and people that are difficult in a written text through the use of mime and dance. As Ciaran Ross notes in relation to the authors tasked with translating the original texts into the English and other languages, the company is required "to identify and convey the cultural beliefs and values that constitute the essence of the Blasket Islands" (127). While Paul O'Brien argues that "Peig's narrative was edited and censored to match the conservative morality of the Irish state" and "[a]11 the earthiness, the sensuality, and the fun was removed" (36), Oileán presents much of the wildness of the island, aware from local stories of the impressions the island women in particular made on people on the mainland.

A motivating factor for commemorating the community of the Blasket Islands is the uniqueness of the culture, which is presented to us initially in the books and later through the staged production. While Ross notes that "The translations, as a mode of representation, serve to confirm Blasket uniqueness, exemplarity, and creativity, and yet seek to liberate these from 
the notion that it was a civilization doomed to extinction in the evolutionary history of nationstate formations" (124), Oileán accepts that the islands will be abandoned, created as it was fifty years following the abandonment of the islands. However, the notion of timelessness is central to the concept of the theatrical performance, the hook upon which the audience are drawn to believe in the island.

Oileán provides a frame through which the stories of the Blasket Islanders may be reread and experienced afresh. There is a sense of a timeless world lost in time brought to life by the characters that inhabit this dimension and are present in front of an audience. The ability to engage with these characters is crucial for the success of this sense of timelessness. Reflecting on An tOileánach, Ross states:

The paradox in producing a sense of cultural timelessness is that such timelessness must be provided with and grounded in a believable story, a personal history, a series of moments characterized by fullness and vigour. This singular voice correlates with the formation of the Blasket subject - the islandman - who speaks with two voices: on the one hand, a unique private and original voice, and on the other, an exemplary collective common voice, the voice of a spokesman. (121)

In contrast to the individual voices of Peig and An tOileánach, Oileán presents the story of a community, bringing together the individual voices of the books into one cohesive narrative. In this translation, the spokesman or narrator is replaced by the director. The focus of commemoration is that of the community and not the individual. However, the use of music, song and dance allows for the recognition of individual talents and creativity, such as the singing of a song to the visiting scholar, the demonstration of step dancing and the performance of "Port na bPúcaí". These characters become part of a believable narrative and the audience develops an empathy with their joys and suffering that generates enhanced connection with what is being commemorated.

Putting the works of the Blasket islanders on stage in the form of a folk theatre presentation, in which there is no dialogue, is an act of translation that mirrors the translation of the works from one language to another. As the translators of An tOileánach note, "the language, like the life, is largely medieval - vigorous, direct, rich in oaths and asseverations, and delighting in neat and witty turns of phrase which are largely lost in translation" (Flower ix). It is by interpreting the language through dance and gesture that Oileán attempts to capture the essence of the language and reach a wider audience, an audience that is often comprised primarily of tourists, many of whom do not speak English and few of whom have any knowledge of the Irish language. It is worth noting that the Blasket writers were motivated to write by the impending loss of the language, often by foreigners who came to study the language. ${ }^{14}$ This echoes Arnold Dreyblatt's assertion that "an archive is a representation of mankind's endless battle against the disappearance of information from the past; an attempt to freeze and keep forever" (49). Like the books, the production tells "the tale not of an attainable perennial ideal, such as critics have fastened onto, but of a civilization on its last legs, certainly a vanishing one" (Ross 120). The islands, now abandoned, live on in a stylised and theatrical manner in the performances of Siamsa Tíre.

That foreign audiences should take such interest in a production inspired by the Blasket Islands is not incongruent with the history of the islands themselves. Although my experience has included positive reception from audiences from and in west Kerry and including both former islanders and their descendants, there may be a contrast between the experience of a tourist and that of a local person. Wulff notes: 
Travelling to an island might be experienced as a trip back in time, not least if you are an Irish expatriate going back to visit your grandparents' country of origin. Still, this pastness, especially when it risks being conflated with ideas of backwardness, is not always appreciated among Irish people living in Ireland. (63)

It is interesting to note that while many local people attended performances by the company in the early years, these have been largely replaced by tourists in recent decades (Ahern, Interview). However, interviews with cast members in 2012 revealed that many of them felt a sense of pride in the nature and standard of the show and were delighted when friends and relatives attended performances.

\section{Conclusion}

Oileán is at once a commemoration of a lost community, a celebration of Irish culture as it was captured on the Blasket Islands, and a performance by a contemporary community of their intangible cultural heritage in a manner that reflects their talents and creativity. It is both nostalgic and current, attracting audiences from all around the world who desire to experience the south west of Ireland. Luke Gibbons writes: "The hankering for a return to nature and the simple life ... is a form of nostalgia for a world which was lost, and is simply an attempt to restore to the countryside an ideology which was taken from it in the first place" (88). Siamsa Tíre has developed a form of folk theatre that aims to present on-stage material that draws from Irish folklore and traditions, not only in a creative and aesthetically pleasing manner but also in a way that presents opportunities for commemoration and a celebration of the past that engages contemporary audiences. The production involving a local, semi-professional cast who repeatedly perform the production together, changes the commemoration from an event to a way of life, removing the focus from the abandonment of the Great Blasket Island in 1953 to a celebration of the unique culture and creativity of the people who lived there and the adaptation of their cultural in the present.

Utilising the archive of literature constructed by the island writers, Oileán presents an engaging commemoration that interprets the culture of the past for varied and diverse audiences in an accessible manner using music, song and dance. Beginning in the contemporary world, the production invites the audience on a journey to the Blaskets, acknowledging the change of temporality. There is a sense of escapism and a romanticised representation of island life but the fun and frivolity that is focused on in the production is balanced by the reality of death and emigration at the climax of the production. The final scenes may be interpreted as an acknowledgement that the culture of the islanders can survive, albeit in new contexts of literature and theatre. Music, song and dance, drawn from the tradition and reshaped by artists, play an important role in the survival of the knowledge and culture.

Reflecting on the role of literature and art in the representation of Ireland, Patrick Duffy notes, "the writing of Ireland and its landscapes is also implicated in the flexibilities and fluidities of contested constructions of Irish identity" (66). As the focus in Ireland changes from the rural to the urban, critic Michael Seavor suggests that if Riverdance represents urban Ireland, Siamsa Tíre represents rural Ireland (qtd. in Wulff 115). There is also an attempt in Oileán to find a balance between the celebratory tone of Ó Suilleabháin's Fiche Bliain ag Fás and the harsher realities of Ó Criomhthain's An tOileánach, perspectives perhaps explained in part by the differing life stages of the authors when they wrote their works (Maher 265). Despite potential perceptions of the Siamsa Tíre productions as archaic or inauthentic, the act of performance and the sense of community presented on the stage is a reflection of local cultural reality in the present and a valuable form of commemoration in and 
of itself. In the case of Siamsa Tíre, I argue that the interpretation of the staged production is not just an "illusion that the activities you watch are being done rather than represented" (Kirshenblatt-Gimblett 55), for in the act of performing the actors are themselves engaging in the essence of folk culture - creating something together as a community and enjoying performance. Through the regularity of their performances, primarily for tourists during the summer months, Oileán becomes a ritualised commemoration of island culture. In addition, these performances provide an invaluable opportunity and space for young members of this community to learn of their heritage and engage with the stories of their ancestor. Speaking in a series of interviews conducted during the 2012 summer season, the cast involved in Oileán celebrated their involvement with the company, proud of the heritage that they portray on stage, knowing that they are presenting a theatrical representation of a culture that no longer exists on the Blasket Islands. Through these performances, the music, song and dance of the Blasket Islands is preserved and transmitted, the folklore achieving a second life, albeit in some instances in a stylised manner.

\section{Notes}

${ }^{1}$ Over the course of a number of years, in conversations with myself and others, Ahern has sought to develop a concept of "folk" that informs much of what has been presented in the productions of Siamsa Tíre.

${ }^{2}$ In this context, the work of Barbara Kirsenblatt-Gimblett on museums may be applied as a lens through which to critically examine the works of Siamsa Tíre. While a report written by Ahern in 1972, which led to the establishment of Siamsa Tíre, recognises the potential for the company to attract and entertain tourists, and while much funding for the company may be related to tourism initiatives, tourism was not viewed as a core focus for the development and presentation of folk theatre. Despite some criticism, the continued relevance of traditional themes for tourism in the twenty-first century and the compatibility of rural Irish folk imagery for entertainment with the promotion of a modern, educated and cosmopolitan Ireland for business is highlighted by Cronin and O'Connor.

${ }^{3}$ Debates on tradition and innovation in Irish traditional music abounded in the 1990s, in part exemplified by the proceedings of the Crossroads Conference held in 1996 (Vallely et al). Siamsa Tíre's experimentation with the integration of contemporary dance approaches alongside local traditional dance in pieces such as Idir Eatartha / Between Worlds (comp. Mícheál Ó Suilleabháin) and the exploration of other folk traditions including Spanish Flamenco and Bulgarian traditions, as well as involvement in The Seville Suite (comp. Bill Whelan) locates Siamsa Tíre within contemporary creative arts developments and relates their work to the discourse that emerges in response to concepts of tradition and innovation at this time.

${ }^{4}$ The importance of place names in Irish culture is widely examined but the inclusion of place names as part of the soundscape in Oileán is undeveloped and the full meaning is not grasped by the audience.

${ }^{5}$ I was the piano player in the initial production and later played many of the male roles on stage in over 100 performances in Tralee and on tour throughout Ireland. I also observed many performances as Season Director during the summer of 2012. The short performance ethnographies presented in this paper represent an amalgam of notes and reflections spread across the first ten years of the production Oileán.

${ }^{6}$ The production would also appear to be informed by the booklet Na Blascaodai / The Blaskets, written by Pádraig Ua Maoileoin (1913-2002), from Dunquin, which provides information on, amongst other things, the way of life of the islanders, social activities and recreation including a section on songs and dances, and information on visitors to the island and their legacy.

7 A brief promotional video by the company may be viewed here: https://www.youtube.com/watch?v=g4EXAZ8XuQo

${ }^{8}$ Referencing the work of Nuala Johnson, Brian Graham emphasises "...the hegemonic image of the West of Ireland as the cultural heartland of the country was an essential component of the late nineteenth-century construction of an Irish nationalism which, in its dependence on a Gaelic iconography, was to prove exclusive rather than inclusive, particularly when its representations became fused with Catholicism. Strongly reinforced by the intellectual elite of early twentieth-century Ireland, the 'West' became an idealised landscape, populated by an idealized people who invoked the representative, exclusive essence of the nation through their Otherness from Britain" (7).

${ }^{9}$ Robin Flower (1881-1946) was an English poet and scholar who visited the Blasket Islands where he acquired the name Bláithín (little flower). His works include a translation of Tomás O'Crohan (1955) and a memoir entitled The Western Island (1944). 
${ }^{10}$ While the game of Gaelic Football is most often associated with Co. Kerry, the custom of playing hurling at Christmas on the white strand is included in the writing of Tomás Ó Criomhthain.

11 In a pamphlet available from the Blasket Centre, Pádraig Ua Maoileoin (1913-2002) wrote: "While the mainland depended on the Jews harp or melodeon, they had the fiddle on the Island, and a unique style of playing. It was a soft gentle style that would waken the dead from the grave with its serenity and tenderness. It had an otherworld quality. The Súilleabháin, Catháin and Dálaigh families were the fiddlers. Some musicians managed to craft their own fiddles. They had a great abundance of songs: Raghadsa is mo Cheaití ag Válcaeireacht (I Will Go Strolling with my Katy), Bá na Scaelaga (Skelligs Bay), Réchnoc Mná Duibhe (The Dark Woman's Smooth Hills), Cailín Deas Crúite na mBó (The Pretty Milkmaid), Beauty Deas an Oileáin (The Fine Beauty of the Island), and the many other songs composed by Seán Ó Duinnshléibhe. They had many more songs, too numerous to mention, and no shortage of singers either. Tomás Ó Criomhthain sang Caisleán Uí Néill, a much-loved song, at his own wedding. They liked to dance a set, or perhaps an eight-hand or four-hand reel, but only a few of the Islanders maintained the tradition of dancing solo". Available from http://www.dinglepeninsula.ie/home/the-blasket-islands/history-heritage-of-the-blasket-islands/11-blasket-islands-na-blascaodai.html (accessed 20 May 2016).

${ }^{12}$ Hugh Shields comments on Ó Criomhtainn's use of "Caisleán Uí Néill” and the context or motivation for singing it in Narrative Singing in Ireland (79-80), which is also taken up by Lillis Ó Laoire in On a Rock in the Middle of the Ocean (206-210).

${ }^{13}$ Keening traditions, where women gather and wail or vocalise in lament at a funeral, are described in Ó Madagáin.

${ }^{14}$ For example Robin Flower and Carl Marstrader.

\section{Works Cited}

Ahern, Pat and Patrick O'Sullivan and Partners, Architects. A Plan for Fostering the Growth of Traditional Irish Folk Culture. Unpublished. 1972.

Ahern, Seán. Interview with Author. Listowel, 31 July 2012.

Almqvist, Bo. "The Irish Folklore Commission: Achievement and Legacy". Béaloideas, Iml. 45/47 (1977 - 1979): 6-26.

Banham. Martin, ed. The Cambridge Guide to Theatre. Cambridge: Cambridge University Press, 1995.

Barry, Sebastian. Prayers of Sherkin. Methuen, Mass.: Heinemann, 1991.

Beiner, Guy. "Negotiations of Memory: Rethinking 1798 Commemoration". The Irish Review 26 (2000): 60-70.

Brennan, Helen. The Story of Irish Dance. Dingle: Brandon, 1999.

Cronin, Michael and Barbara O'Connor. Irish Tourism: Image, Culture and Identity. Vol. 1. Clevedon: Channel View Publications, 2003.

Dreyblatt, Arnold. “Questionnaire 2". Performance Research 7. 4 (2002): 48-49.

Duffy, Patrick. "Writing Ireland: Literature and Art in the Representation of Irish Place". In Search of Ireland: A Cultural Geography. Ed. Brian Graham. London: Routledge, 1997. 64-84.

Flower, Robin. The Western Island or The Great Blasket. Oxford: Clarendon Press, 1944.

Foley, Catherine. Step Dancing in Ireland: Culture and History. Farnham: Ashgate, 2013.

- "Cultural Tourism, Meitheal, and Re-presentation of Heritage: Traditional Step Dancing and Siamsa Tire, the National Folk Theatre of Ireland". Yearbook for Traditional Music 47 (2015): 141-160.

Gibbons, Luke. Transformations in Irish Culture. Notre Dame, Indiana: University of Notre Dame Press, 1996.

Gibson, Christopher R. and John Connell. Music and Tourism: On the Road Again. Vol. 19. Clevedon: Channel View Publications, 2005.

Gillis, John R. "Places Remote and Islanded (Geography, Environment)". Michigan Quarterly Review 40.1 (2001): 39-58. 
Graham, Brian. In Search of Ireland: A Cultural Geography. London: Routledge, 1997.

Hickey, Dónal. "Blanket Development Ban Proposed to Protect Great Blasket Island". Irish Examiner. 22 December 2011.

Honko, Lauri. Theoretical Milestones: Selected Writings of Lauri Honko. Helsinki: Suomalainen Tiedeakatemia, 2013.

Hurley, Oliver. Interview with Author. Tralee, 25 June 2013.

Johnson, Nuala. "Building a Nation: An Examination of the Irish Gaetlatch Commission Report of 1926". Journal of Historical Geography 19 (1993): 157-68.

Kearney, Daithí. "The Evolution of Irish Folk Theatre". Sharing Cultures - Proceedings of the 3rd International Conference on Intangible Heritage. Eds. R. Amoêda, S. Lira and C. Pinheiro. Lisbon: Green Lines Institute, 2013. 127-128.

. "Siamsa Tíre: The National Folk Theatre of Ireland". The Encyclopaedia of Music in Ireland. Dublin: UCD Press, 2013. 933-934.

. "Pioneer of Folk Theatre, Pat Ahern Of North Kerry". Irish Music Magazine 237 (2015): 41.

. "Samhain: Two Directions on a Theme". New Crops, Old Fields: Reimagining Irish Folklore. Ed. Conor Caldwell and Eamon Byers. Bern: Peter Lang, 2016. 99-124.

Kirshenblatt-Gimblett, Barbara. Destination Culture: Tourism, Museums and Heritage Berkeley: University of California Press, 1998.

Lowenthal, David. "Islands, Lovers, and Others". Geographical Review 97.2 (2007): 202229.

Lucey, Anne. "Proposal to make the Great Blasket a World Heritage Site". The Irish Times. 18 June 2003.

MacDonnell, James. Interview with Author. Tralee, 8 August 2012.

Maher, Eamon, 2008. "Island Culture: The Role of the Blasket Autobiographies in the Preservation of a Traditional Way of Life". Studies: An Irish Quarterly Review 97. 387 (2008): 263-274.

Morash, Chris and Shaun Richards. Mapping Irish Theatre: Theories of Space and Place. Cambridge: Cambridge University Press, 2013.

Motherway, Susan. "Siamsa Tíre". Companion to Irish Traditional Music. Ed. Fintan Vallely. Cork: Cork University Press, 2011. 615.

Mulrooney, Deirdre. Irish Moves: An Illustrated History Of Dance And Physical Theatre in Ireland. Dublin: Liffey Press, 2006.

O'Brien, Paul. "Primitive Communism and The Blasket Islands". Irish Marxist Review 4.12 (2015): 32-39.

Ó Cinnéide, Barra. Riverdance: The Phenomenon. Dublin: Blackhall Publications, 2002.

O'Crohan, Tomás. The Islandman. Trans. Robin Flower, from the Irish An tOileánach (1951). Oxford: Oxford University Press, 1955.

Ó Criomhtháin, Tomás. An tOileánach. Dublin: Helicon Teoranta, 1980 (1929).

Ó Giolláin, Diarmuid. Locating Irish Folklore: Tradition, Modernity, Identity. Cork: Cork University Press, 2000.

Ó Laoire, Lillis. On a Rock in the Middle of the Ocean: Songs and Singers in Tory Island, Ireland. Lanham, MD: Scarecrow Press, 2005.

Ó Madagáin, Breandán. Caointe Agus Seancheolta Eile: Keening and Other Old Irish Musics, Indreabhán, Conamara: Cló Iar-Chonnachta, 2005.

O'Toole, Fintan. The Ex-Isle of Erin: Images of a Global Ireland. Dublin: New Island, 1997.

-. "Irish Theatre - The State of the Art". Theatre Stuff: Critical Essays on Contemporary Irish Theatre. Ed. Eamonn Jordan. Bern: Peter Lang, 2000. 46-58. 
Ó Suilleabháin, Mícheál. Idir Eatarthu / Between Worlds. Dublin: Contemporary Music Centre, n.d.

Phelan, Sharon. Dance in Ireland: Steps, Stages and Stories. Newcastle upon Tyne: Cambridge Scholars Press, 2014.

Ross, Ciaran. "Blasket Island Autobiographies: The Myth and Mystique of the Untranslated and the Untranslatable". Translation and Literature 12. 1 (2003): 114-143.

Royle, Stephen A. "From the Periphery of the Periphery: Historical, Cultural and Literary Perspectives on Emigration from the Minor Island of Ireland”. Small Worlds, Global Lives: Islands and Migration. Ed. Russell King and John Connell. London and New York: Pinter, 1999. 27-54.

Runia, Eelco. "Burying the Dead, Creating the Past". History and Theory 46.3 (2007): 313 325.

Sayers, Peig. An Old Woman's Reflections. Dublin, Clolucht an Talboidigh, 1936.

Schwartz, Barry. "The Social Context of Commemoration: A Study in Collective Memory". Social Forces 61. 2 (1982): 374-402.

Seavor, Michael. "Stepping into Footprints: Tradition and the Globalization of Irish Dance". Dance in a World of Change: Reflections on Globalization and Cultural Difference. Ed. Sherry Shapiro. Leeds: Human Kinetics, 2008. 3-16.

Shay, Anthony. Choreographic Politics: State Folk Dance Ensembles, Representation and Power. Middletown, CT: Wesleyan University Press, 2002.

Shields, Hugh. Narrative Singing in Ireland: Lays, Ballads, Come-All-Yes, and Other Songs. Dublin: Irish Academic Press, 1993.

Siamsa Tíre. Website. 20 May 2016. www.siamsatire.ie.

Swift, Caroline and Christopher Morash. "Ireland: Music Theatre, Dance Theatre". World Encyclopaedia of Contemporary Theatre Volume 1: Europe. Eds. Peter Nagy, Phillippe Rouyer and Don Rubin. London: Routledge, 2013. 482-486.

Synge, John Millington. The Aran Islands. Dublin, London: Maunsel and Co. Ltd., 1907.

Theodores, Diane. "Report - A Dance Critic in Ireland". Dance Chronicle: Studies in Dance and the Related Arts. 19.2 (1996): 191-211.

Titon, Jeff Todd. "Knowing Fieldwork". Shadows in the Field: New Perspectives for Fieldwork in Ethnomusicology. Ed. Gregory F. Barz and Timothy J. Cooley. New York: Oxford University Press, 1997. 87-100.

Ua Maoileoin, Pádraig. Na Blascaodaí / The Blaskets. Dún Chaoin, Co. Chiarraí: Ionad an Bhlascaoid Mhóir / The Blasket Centre. N.d. 20 May 2016. http://www.dinglepeninsula.ie/home/the-blasket-islands/history-heritage-of-the-blasket-islands/11blasket-islands-na-blascaodai.html

Uí Ógáin, Ríonach and Tom Sherlock, eds. The Otherworld: Music and Song from Irish Tradition. Dublin: Four Courts Press, 2012.

Vallely, Fintan, H. Hamilton, E. Vallely and L. Doherty. Crosbhealach an Cheoil: Tradition and Change in Irish Traditional Music. Dublin: Whinstone Music, 1999.

Whelan, Bill. The Seville Suite. Tara Records Ltd. 1992.

Wulff, Helena. Dancing at the Crossroads: Memory and Mobility in Ireland. Vol. 1. Oxford, New York: Bergahn Books, 2007.

Received: 14 February 2017 Revised version accepted: 28 September 2017

Daithí Kearney is a lecturer in Music at Dundalk Institute of Technology. He is also ethnomusicologist, geographer and performer. His research is primarily focused on Irish 
traditional music but extends to include performance studies, community music and music education. Daithí has toured regularly as a musician, singer and dancer with a number of groups including Siamsa Tíre, The National Folk Theatre of Ireland. In 2012 he released an album with Cork accordion player John Cronin entitled Midleton Rare, which is related to a wider research project on the music and musicians of the Sliabh Luachra region. In 2017 he released an album of new compositions with Dr Adèle Commins entitled A Louth Lilt. A graduate of University College Cork, recent publications include contributions to the Companion to Irish Traditional Music (ed. Vallely, 2012), Ancestral Imprints (Ed. Smith, 2012), the Encyclopaedia of Music in Ireland (ed. White and Boydell, 2013), Spacing Ireland (Crowley and Linehan, 2013) and New Crops, Old Fields (ed. Caldwell and Byers, 2016).

daithi.kearney@dkit.ie 